ppi $201502 Z U 4645$

Esta publicación científica en formato digital es continuidad de la revista impresa ISSN-Versión Impresa 0798-1406 / ISSN-Versión on line 2542-3185Depósito legal pp $197402 Z$ U34

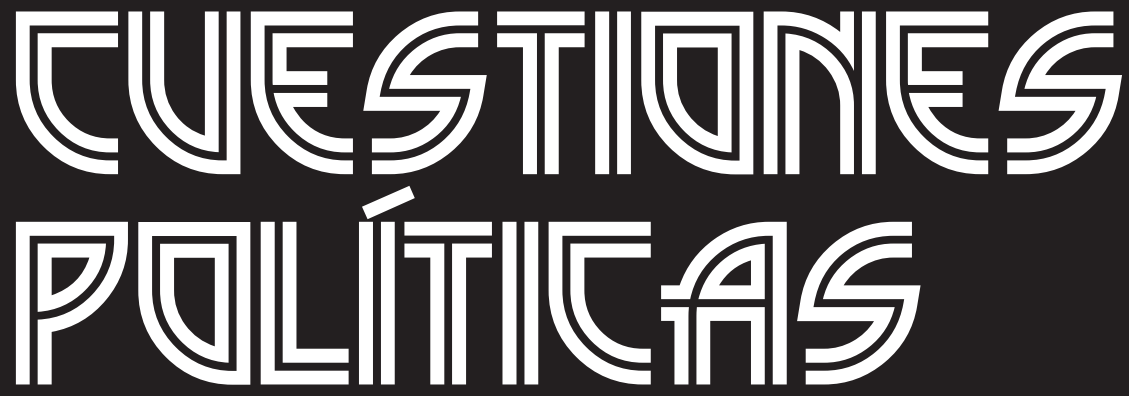

Instituto de Estudios Políticos y Derecho Público "Dr. Humberto J. La Roche" de la Facultad de Ciencias Jurídicas y Políticas de la Universidad del Zulia Maracaibo, Venezuela
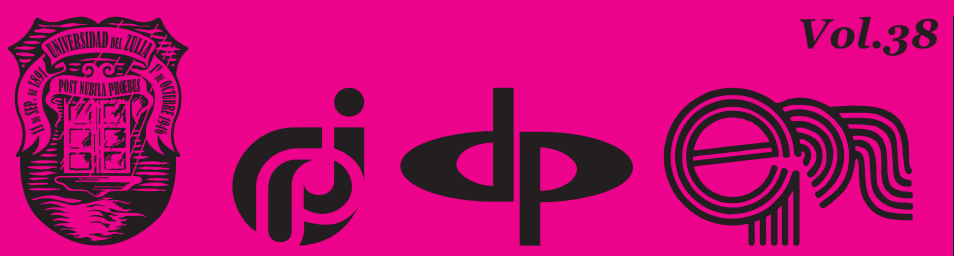

$N^{\circ}$ Especial 1era Parte 2020 


\title{
Methods and Procedural Forms of Protection of Personal Non-Property Patent Rights in Russia
}

\author{
DOI: https://doi.org/10.46398/cuestpol.38e.32
}

\author{
Ruslan Borisovich Sitdikov * \\ Ravil Mansurovich Sadykov ** \\ Golubtsov Gennadievich Valery ***
}

\begin{abstract}
The article discusses the legal regulation of the application of civil law methods of non-patrimonial personal rights in the protection of patent rights. Methodologically, the scientific method and the technique of documentary research close to legal hermeneutics were made. By way of conclusion, everything indicates that there is no mandatory administrative procedure for resolving authorship disputes in the patent dispute chamber in Russia. In addition, it was revealed that the provisions of Part 4 of the Civil Code of the Russian Federation with respect to the Protection of Non-Property Personal Patent and Intellectual Rights were unsuccessfully established and created legal uncertainty, as only part of the above methods of civil and personal rights have worked in non-property litigation. As a recomjunction, it is proposed to extend the scope of Article 1407 of the Civil Code of the Russian Federation "publication of the judicial decision on patent infringement" and related administrative procedures for cases of violation of non-patrimonial personal patent rights.
\end{abstract}

Keywords: protection of non-patrimonial personal rights; patent infringement; judicial and extrajudicialproceedings; legislation of the Russian federation; administrative procedures.

Asociate professor of the department of Environmental, Labor law and Civil procedure of the Law faculty of the Kazan Federal University. ORCID ID: http://orcid.org/oooo-0002-1116-8031. Email: ruslan.sitdikov@gmail.com

** Post-graduate of the department of business and energy of the Law faculty of the Kazan Federal University. ORCID ID: https://orcid.org/oooo-0002-7122-8817. Email: rm.sadykov@yandex.ru

*** Professor, head of the Department of business law, civil and arbitration procedure of the Perm state national research University. ORCID ID: https://orcid.org/oooo-0003-3505-2348. Email: vg2009@ yandex.ru 


\section{Métodos y formas procesales de protección de los derechos de patente personales ajenos a la propiedad en Rusia}

\section{Resumen}

El artículo analiza la regulación legal de la aplicación de métodos de derecho civil de derechos personales no patrimoniales en la protección de derechos de patente. En lo metodológico se hizo del método científico y de la técnica de investigación documental próxima a la hermenéutica jurídica. A modo de conclusión todo indica que no existe un procedimiento administrativo obligatorio para resolver disputas de autoría en la cámara de controversias sobre patentes en Rusia. Además, se reveló que las disposiciones de la parte 4 del código civil de la federación de rusia con respecto a la protección de los derechos de patentes e intelectuales personales no relacionados con la propiedad se establecieron sin éxito y crearon inseguridad jurídica, ya que solo una parte de los métodos anteriores de derechos civiles y personales han funcionado en los litigios sobre esta materia. Como recomendación se propone ampliar el alcance del artículo 1407 del código civil de la federación de rusia "publicación de la decisión judicial sobre infracción de patente" y los procedimientos administrativos relacionados para los casos de violación de derechos de patentes personales no patrimoniales.

Palabras clave: protección de los derechos personales no patrimoniales; infracción de patentes; procedimiento judicial y extrajudicial; legislación de la federcaion rusa; procedimientos administrativos.

\section{Introduction}

Getting to the study of personal non-property patent rights, one should first determine the concept and list of these rights. The law does not define the concept of personal non-property patent rights, but from a number of general provisions of civil law and legislation on the protection of intellectual property rights in this article, an attempt will be made to isolate and consider their features in order to further analyze the methods and forms of their protection.

The legal basis for the protection of personal non-property patent rights consists of the following provisions of the law. According to paragraph 3 of the Review of the Practice of Court Consideration of Disputes on the Protection of Honor, Dignity and Business Reputation (approved by the 
Presidium of the Supreme Court of the Russian Federation on 16.03.2016), "The exercise of constitutional rights aimed at protecting intangible goods is carried out in the manner prescribed by Article 12, clause 5 of Article 19, Articles 150, 152, 1099 and 1100, clause 3 of Article 1251, clause 2 of Article 1266 of the Civil Code of the Russian Federation (hereinafter - the CC RF)". It seems appropriate to analyze the above norms.

The above norms will be the research subject in this article.

\section{Methods}

The methodological basis of this work is specified in the application of the general principles of scientific knowledge (objectivity, comprehensiveness, completeness of research) and general scientific methods of cognition (analysis, synthesis, approach, deduction, etc.), as well as the system of methods and techniques for studying legal phenomena. During the study, the authors applied special (general theory of systems) and private-scientific (comparative-legal, formal-legal) methods.

\section{Results And Discussion}

Article 150 of the CC RF actually discloses the content of objects of the personal non-property civil rights - intangible goods. At the same time, the list of intangible goods is indicated open, but authorship is directly indicated in it, and the right to it is intellectual. Here, the legislator formulated the main signs of intangible goods, and accordingly, the rights to them:

- Intangible and non-property nature (which follows from the names of these goods and rights to them).

- Inalienability and inexpressibility in another way.

- Belonging by force of law or from birth.

We consider it necessary to note that the literal meaning of the phrase "intangible good" does not necessarily mean that this "good" cannot be proprietary (since the word "intangible" rather means "non-material") or that it cannot belong to a legal entity. In clause 11 of Article 152 of the CC RF, the legislator directly uses the phrase "business reputation of a legal entity". However, in other situations, the legislator uses the concept of "intangible goods" primarily as an object of personal non-property rights of a citizen, and it is logical that the above signs are fully implemented in such cases. 
Ruslan Borisovich Sitdikov, Ravil Mansurovich Sadykov y Golubtsov Gennadievich Valery
476 Methods and Procedural Forms of Protection of Personal Non-Property Patent Rights in Russia

We also believe that one can highlight the lack of artificial (legislative) limitation of the protection term as another sign of personal non-property rights.

Regarding the signs of personal non-property patent rights, it should be noted that since inventions, utility models and industrial designs are protected only under the condition of their state registration, the corresponding personal non-property rights to them should also be protected under the condition of such registration of the above objects. Therefore, one can single out such an additional sign of personal non-property patent rights as the presence of state registration of the corresponding object. It should be noted that the state registration of the patent rights object is an element of the right to obtain a patent, which may be alienated to the author. Even of the application for registration is filed, it can be withdrawn by the applicant at his/her/its own discretion. Therefore, the emergence and recognition of the right of invention, utility model or industrial design author depends on the rightholder's will to obtain a patent This can also be considered a specific feature of personal non-property patent rights.

The composition of personal non-property intellectual rights is disclosed only in Article 1228 of the CC RF, where they include the right of authorship and the right to a name. But their list is open. The signs of personal nonproperty intellectual rights allocated in the specified article correspond to those highlighted in Article 150 of the CC RF. It is also additionally indicated such a sign as the impossibility of waiver of the author's moral rights. Patent law, primarily Article 1345 of the CC RF, does not supplement the composition of personal non-property rights, and, moreover, narrows it down, indicating only the copyright and not indicating the right to a name. Moreover, Part 3 of this article, using the term "other" rights instead of the term "another" rights, introduces some legal uncertainty regarding the openness/closeness of the composition of patent rights, including personal non-property rights.

An attempt to eliminate this ambiguity was made in clause 32 of the Resolution of the Plenum of the Supreme Court of the Russian Federation No. 10 dated 23.04.2019 "On the Application of Part 4 of the Civil Code of the Russian Federation". In our opinion, at least with the fact that the right to obtain a patent and the author's right to remuneration should not be attributed to personal non-property intellectual (and, therefore, to patent) rights, it is necessary to agree and, moreover, directly enshrine this in law.

As for the lack of a special indication of the right to a name of the invention, utility model or industrial design author, we believe that this is a drawback that needs to be addressed. Thus, if one literally reads clause 2 of Article 1228 of the CC RF, it follows that the right to a name is protected only in cases stipulated by the code. And as already mentioned above, it is not expressly stipulated in Chapter 72 of the CC RF in case of patent 
rights. This circumstance was also noted in the legal literature (Bogdanova, 2019; Budylin \& Osipova, 2007). At the same time, the right to a name of the author of the patent rights object is indicated in clause 1 of Article 1394 of the CC RF, according to which the "Federal executive authority on intellectual property publishes (in the official bulletin) the information on granting a patent for an invention or utility model, including the author's name (if the author did not refuse to be mentioned as such), name or title of the patent holder, name and formula of the invention or utility model". In continuation of this rule, there is a column in the approved invention patent application forms, where the author has the right to ask Rospatent not to mention himself/herself/itself when publishing information about the invention and patent. Similar forms and capabilities are stipulated for patent applications for utility models and industrial designs. We believe that these norms of by-laws and regulations are the actual implementation of the right to a name of the invention, utility model, industrial design author.

However, nothing is said about the possibility of using a pseudonym in these documents. Let's consider a little this moment. Since paragraph 2 of clause 1 of Article 19 of the CC RF provides for the possibility of using a pseudonym by a citizen only in cases stipulated by law, and such cases in the field of intellectual property protection are provided only for the objects of copyright and related rights, it can therefore be concluded that the author of the patent rights object has no right to a pseudonym. In our opinion, this circumstance seems illogical in view of the following.

Firstly, it could be assumed that this is due to the state registration of patent rights. However, for example, such copyright objects as computer programs can also be registered with Rospatent, and the possibility of specifying a pseudonym is provided in the approved application form for their registration.

Secondly, it is known that industrial designs are the works of design and can be protected at the discretion of the copyright holder both as an industrial design and as a copyright object by their legal nature. This was also mentioned in clause 74 of the Resolution of the Plenum of the Supreme Court of the Russian Federation No. 10 dated 23.04.2019 "On the Application of Part 4 of the Civil Code of the Russian Federation", as well as in the scientific literature (Hazieva Guzel et al., 2018; Sannikova \& Kharitonova, 2019) and judicial practice. Speaking about the composition of personal non-property patent rights, it is also necessary to pay attention to such a concept as inventive law, used in Article 7.12 of the Administrative Offense Code of the Russian Federation (hereinafter - the AOC RF) "Violation of Copyright and Related Rights, Inventive and Patent Rights" and Article 147 of the Criminal Code of the Russian Federation "Violation of Inventive and Patent Rights". 
Meanwhile, neither the disposition of the above articles, nor the content of other acts clarifying the application of the above code articles, including the Resolution of the Plenum of the Supreme Court of the Russian Federation No. 14 dated 26.04.2007 "On the Practice of Courts Considering Criminal Cases of Violation of Copyright, Related, Inventive and Patent Rights, as well as on the Illegal Trademark Use" ,the Letter of the Federal Customs Service of the Russian Federation No. 01-06/24387 dated 29.06.2007 "On Submission of the Methodological Recommendations", do not separately disclose the concept of "inventive rights". The term "inventive rights" is also used in a number of departmental acts, for example, in the Regulation on the Invention Bodies of the Armed Forces of the Russian Federation. We believe that this term is obsolete, remaining from the time when inventions in the USSR were protected not by patents, but by copyright certificates, or used in some foreign countries (WIPO Intellectual Property Handbook; Correa, 2007) At present, it should be completely eliminated in all branches of law for the purpose of legal certainty.

The legal basis for the protection of personal non-property patent rights consists of the following provisions of the law.

According to paragraph 3 of the Review of the Practice of Court Consideration of Disputes on the Protection of Honor, Dignity and Business Reputation (approved by the Presidium of the Supreme Court of the Russian Federation on 16.03.2016), "The exercise of constitutional rights aimed at protecting intangible goods is carried out in the manner prescribed by Article 12, clause 5 of Article 19, Articles 150, 152, 1099 and 1100, clause 3 of Article 1251, clause 2 of Article 1266 of the Civil Code of the Russian Federation (hereinafter - the CC RF)". It seems appropriate to analyze the above norms.

As we know, Article 12 of the CC RF defines general ways of protecting civil rights.

Clause 5 of Article 19 of the CC RF establishes such methods of protecting the right to a citizen's name as the right to demand a refutation, compensation for harm caused and compensation for non-pecuniary damage.

Article 150 of the CC RF additionally provides for such methods of protecting intangible goods as recognition by a court of the fact of violation of personal non-property rights, publication of a court decision on a violation committed, suppression or prohibition of actions that violate or create a threat of violation of personal non-property, rights or encroach or threaten to infringe on intangible good.

Article 152 of the CC RF establishes such protection methods as refutation, deletion of relevant information, suppression or prohibition of further dissemination of this information by seizing and destroying it 
without any compensation made in order to introduce into civil circulation the copies of tangible media containing the specified information, if removal of relevant information is impossible without destruction of such copies of tangible media.

Articles 1099 and 1100 of the CC RF determine the rules for compensation for non-pecuniary damage.

The general rules for the protection of personal non-property rights to the intellectual activity results and individualization means are also enshrined in Article 1251 of the CC RF, especially devoted to this issue. According to it, the personal non-property rights are protected in such ways as:

- Right recognition.

- Restoration of the situation that existed before the right violation.

- Suppression of actions that violate the right or create a threat of its violation.

- Compensation for non-pecuniary damage.

- Publication of a court decision on the violation.

Article 1266 of the CC RF is devoted to work (copyright object) protection against distortion.

In fact, the general methods of protecting civil rights specified in Article 12 of the CC RF are partially re-set in in the chapter concerning the intellectual property rights. At the same time, it is clearly visible that the methods of protecting personal non-property intellectual rights listed in Part 4 of the CC RF are incompletely re-written and/or specified in it, which creates a certain difficulty in their understanding. Thus, Article 1251 of the CC RF does not indicate the applicability of the provisions of Article 150 of the CC RF to the protection of personal non-property intellectual rights. We believe that it would be more correct or complete to repeat all the general methods of civil rights and to supplement or specify them, or not to repeat them at all, confining ourselves only to references, and point out only special ways to protect the intellectual rights and/or features of the application of general methods in relation to the protection of the intellectual property.

Paragraph 8 of Part 4 of the CC RF is devoted to special rules for the protection of patent rights. However, the title and content of the articles contained therein do not specify and do not supplement the above methods of protecting personal non-property rights, but rather contain liability measures for violation of not personal, but exclusive rights, and determine the competence of courts and administrative bodies to resolve disputes on the protection of intellectual rights. 
Speaking about the civil legal protection of personal non-property patent rights, some provisions of the Resolution of the Plenum of the Supreme Court of the Russian Federation No. 14 dated 26.04.2007 "On the Practice of Courts Considering Criminal Cases of Violation of Copyright, Related, Inventive and Patent Rights, as well as on the Illegal Trademark Use" may be highlighted. Thus, it discloses such violations of personal non-property rights of authors of patent rights objects as disclosure of the essence of the invention, utility model, industrial design, attribution of authorship, coercion to co-authorship.

It should also be noted that the disclosure of the essence of the patent rights object may entail the subsequent impossibility of obtaining a patent due to the fact that the information becomes publicly available in the prior art, as well as other adverse consequences. This, in turn, means that the invention author will remain unrecognized. Violations of personal nonproperty rights, that is, the rights of authorship or the right to a name, should also include an incorrect indication of the authors, their names or pseudonyms, or failure to indicate the invention authors in general.

Now it makes sense to go through each of the above methods of protecting both intellectual and civil rights with a view to their applicability to the protection of patent rights.

The recognition of the right as a way of protection is indicated both in the General Part and in Part 4 of the CC RF, but, as mentioned above, is not specifically mentioned in Chapter 72, devoted to patent rights. We believe that, despite the fact that Article 1251 of the CC RF is applicable to all objects of intellectual property rights, this protection method has some peculiarities of application in relation to those objects for which the rights are subject to state registration, including in relation to patent rights objects. An exact way will be clear after analyzing the other protection methods.

Recognition of right violation. It is noteworthy that Article 1251 of the CC RF does not indicate the applicability of the provisions of Article 150 of the CC RF to the protection of personal non-property intellectual rights and the possibility of using such a protection method as recognition of right violation. This circumstance applies not only to the protection of personal non-property intellectual rights, but also to the exclusive right to the intellectual activity results, as well as to the individualization means.

But in this case, we will study this issue only in relation to the protection of personal non-property rights. We believe that the recognition of right violation in some cases may have independent legal value in the protection of intellectual rights in general, as indicated in the legal literature (Pylaeva \& Nefediev, 2015; Novoselova, 2019). On the other hand, indeed, it is in relation to the protection of personal non-property patent rights that it is difficult to imagine a situation where, for example, it would be important 
for the author only to establish the fact of violation of his/her/its right to a name or copyright, but not to request a corresponding change to the register of patent rights. Nevertheless, we believe that this does not exclude the need for a general legislative consolidation of the possibility of making a claim on the recognition of violation of any intellectual right, including personal non-property patent right.

Such methods as restoration of the situation that existed before the right violation, suppression of actions that violate the right or create a threat of its violation; invalidation of an act adopted by state body or local government (i.e., the author's right to a name and copyright) are interrelated and in fact involve the introduction of appropriate changes to the register of patent rights, as well as the issuance of a new patent through an administrative procedure or in court (Valeev \& Baranov, 2014). Moreover, these methods are interrelated and virtually inalienable from the right recognition. The following should be noted in relation to all of these methods in the aggregate.

Since patent rights are subject to state registration, from the moment of filing a patent application for an invention, utility model or industrial design, the above methods of protecting personal non-property patent rights can be implemented only through the administrative procedures. This is not only Russian, but also worldwide practice (Klien et al., 2018). If the dispute between the authors and the copyright holder (applicant) is peacefully settled in a non-jurisdictional order, then it is possible to amend the application documents during the registration procedure or in the register of registered patent rights. If the dispute is not settled, then the clarification specified in clause 121 of the Resolution of the Plenum of the Supreme Court of the Russian Federation No. 10 dated 23.04.2019 "On the Application of Part 4 of the Civil Code of the Russian Federation" is applicable.

The rules for filing objections, applications and their consideration by the Chamber for Patent Disputes do not provide for a pre-trial administrative procedure for the consideration of such disputes. The judicial procedure is implemented in the Intellectual Property Rights Court, and not in the courts of general jurisdiction, as before.

Publication of a cort decision on violation. Regarding this protection method, it is noteworthy that the protection method stipulated in Article 1407 of the CC RF - publication of a court decision on patent infringement - is applicable to the protection of exclusive rights, but not personal nonproperty rights. This conclusion follows from the fact that if one literally reads paragraph 3 of clause 1 of Article 1229 of the CC RF, which is the only one revealing the concept of illegal (equally "illegal" in the wording of Article 1407 of the Code) use of the intellectual activity result, it turns out that the illegal use of the intellectual activity result considers only those actions that violate the exclusive right, but not personal non-property rights 
The relevant Administrative Rules for the provision of the state service for the publication of court decisions on violations of exclusive rights issued by Rospatent is also devoted only to the protection of exclusive, but not intellectual/patent rights.

We believe that refutation, as a way of protecting the right, can also be of independent importance for the authors of inventions, utility models or industrial designs in cases where publication of a court decision or the amended patent information is insufficient.

We believe that compensation, as a way to protect the author's personal non-property rights, despite the fact that the right to the author's name and the authorship right are non-property rights, may protect the personal non-property patent rights, for example, in cases where the author turned out to be deprived of certain property rights (rights to remuneration) or other benefits (bonuses, opportunities to participate and receive income from various grants, etc.) as a result of incorrect information about his/ her/its authorship.

\section{Final considerations}

1) According to the legislation of the Russian Federation, personal nonproperty patent rights include only the right to a name of the invention, utility model and industrial design author.

2) The signs of personal non-property patent rights are the traditional signs of personal non-property rights: non-property nature, belonging to a citizen, inalienability, belonging by law; and specific to patent rights, such as: availability of state registration of patent rights objects, their indefinite protection, their dependence on occurrence and recognition of the rightholder's will to obtain a patent.

3) It is substantiated that the author's right to a name expressly stipulated in relation to the objects of copyright and related rights also exists for the authors of patent rights objects and should be directly enshrined in the legislation of the Russian Federation on the protection of intellectual property.

4) It is proved that the right to a pseudonym as an element of the right to the author's name should be extended not only to objects of copyright and related rights, but also to the patent rights objects, and implemented both in the provisions of the $\mathrm{CC} \mathrm{RF}$ and in the corresponding application forms for state registration of the patent rights objects. 
6) Violations of personal non-property patent rights include such actions as: attribution of authorship, coercion or other unlawful joining of the co-authors, failure to indicate or incorrect indication of the author's/coauthor's name in the patent application, in a patent for an invention, utility model or industrial design or in any other way.

7) Personal non-property patent rights can be protected by such civil law methods as: right recognition; recognition of right violation; restoration of the situation that existed before the right violation; suppression of actions that violate the right or create a threat of its violation; invalidation of an act adopted by state body or local government (primarily a patent or other acts of Rospatent); law self-defense; indemnification; compensation for nonpecuniary damage; refutation; publication of a court decision on violation.

8) It was revealed that the provisions of Part 4 of the Civil Code of the Russian Federation regarding the protection of personal non-property intellectual and patent rights were set out unsuccessfully and create legal uncertainty, since only part of the above methods of civil rights and personal non-property civil rights are duplicated. 10) Procedural protection of personal non-property patent rights can be exercised:

- in voluntary pre-trial/extrajudicial form by peaceful dispute settlement and subsequent voluntary amendment of the information on patent application or the register of registered patent rights objects;

- in judicial form (in the Intellectual Property Rights Court).

There is no mandatory administrative procedure for resolving authorship disputes in the Chamber for Patent Disputes.

\section{Conclusions}

The above conclusions allow making the following proposals.

It is proposed to completely eliminate the term "inventive law" as an obsolete analogue of the concept of "patent law", excluding it from all legal acts and replacing it with the term "patent law".

It is proposed either to completely eliminate duplication of the above methods of protecting personal non-property rights in the legislation on the protection of intellectual property by making the rules reference, or to duplicate them in full and specify them in relation to the intellectual and patent rights. 
It is also proposed to extend the scope of Article 1407 of the Civil Code of the Russian Federation "Publication of Court Decision on Patent Infringement" and related administrative procedures for the cases of violation of personal non-property patent rights.

\section{Acknowledgements}

The work is performed according to the Russian Government Program of Competitive Growth of Kazan Federal University.

\section{Bibliographic References}

BOGDANOVA, Olena V. 2019. Patent and other rights belonging to the R\&D author, and their protection. Law and Economics. No. 1, pp. $41-48$. "Consultant" Reference Legal System.

BUDYLIN, Sergey; OSIPOVA, Yulia. 2007. "Total Upgrade: Intellectual Property Law Reform in Russia" In: Columbia Journal of East European Law, Legislative Development.

CORREA, Carlos M. 2007. Trade Related Aspects of Intellectual Property Rights. A Commentary on the TRIPS Agreement. Oxford University Press. New York, EE. UU.

HAZIEVA, Guzel B; SITDIKOVA, Roza I; SAFIN, Zavdat F; BLYZNETS, Ivan A. 2018. "The script work in the complex object of copyrights" In: Revista San Gregorio. No. 25, pp. 53-58.

KLIEN, Joseph A; RAO, Patrick M; DALVI, Manoj. 2018. "Competition and consumer privacy in the cyberspace market” In: JIPR. Vol. 23, No. 2-3, pp. $70-85$.

NOVOSELOVA, Luies. A. (Ed.). 2019. Intellectual Property Right, 4. Patent Law: Textbook. - M: Statut. London, England.

PYLAEVA, Yulenda E; NEFEDIEV, Antonio. N. 2015. "Protection of rights to industrial designs: practical aspects" In: Bulletin of the Arbitration Court of the Moscow District. No. 2, pp. 31 - 41. "Consultant Plus" Reference Legal System. 
SANNIKOVA, Larisa V; KHARITONOVA, Yulia S. 2019. "Protection of Patent Holders' Rights under a Conflict of Drug Patents" In: Juridical Sciences. Available online. In: DOI: 10.17072/1995-4190-2019-43-121-145. Fecha de consulta: 14/10/2019.

VALEEV, Denala Kh; BARANOV, Samouel Yu. 2014. "Commentary on the Civil Procedure Code of the Russian Federation” (Chapter 3. Jurisdiction) In: Bulletin of the Civil Process. No. 4, pp. 156-189.

WIPO INTELLECTUAL PROPERTY HANDBOOK: POLICY, LAW AND USE. 2001. Geneva, Switzerland. 


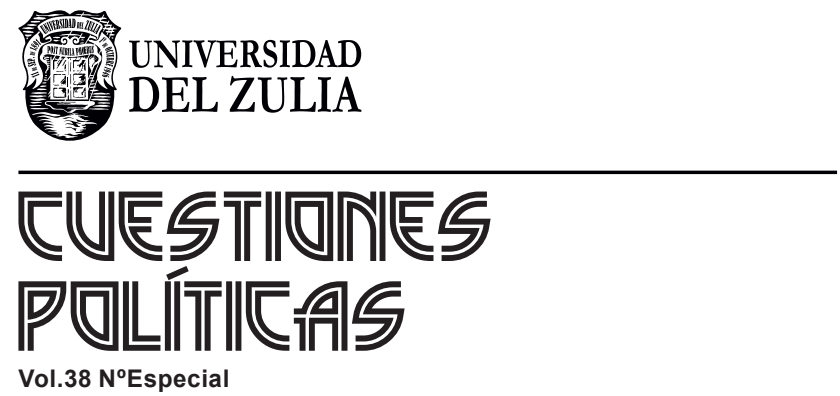

www.luz.edu.ve 